\title{
Differential beta cell responses to hyperglycaemia and insulin resistance in two novel congenic strains of diabetes (FVB-Leprdb) and obese (DBA-Lepob) mice
}

\author{
S. Chua Jr. ${ }^{1}$, S. Mei Liu ${ }^{1}$, Q. Li ${ }^{1}$, L. Yang 1 , V. T. Thassanapaff ${ }^{1}$, P. Fisher ${ }^{2}$ \\ ${ }^{1}$ Division of Molecular Genetics and New York Obesity Research Center, Department of Pediatrics, ${ }^{2}$ Department of Pathology, \\ Columbia University, New York, USA
}

\begin{abstract}
Aims. Our goal was to identify genetic variants that determine the response to insulin resistance and hyperglycaemia. This report documents the diabetes syndrome of two new congenic strains of mice generated by the transfer of the Lepr ${ }^{d b}$ mutation to the FVB/NJ strain and the $L e p^{o b}$ mutation to the DBA/2J strain. Methods. Mice were characterised by measures of blood metabolites and hormones along with challenges with glucose and insulin injections. Histological examinations of the endocrine pancreas and the kidneys were also carried out.

Results. Obese mice of the FVB- $d b$ congenic strain show long-term hyperglycaemia that is primarily due to severe insulin resistance. The hyperglycaemia in the fed state persists despite escalating secretion of insulin and massive increase of pancreatic beta cells. Obese FVB- $d b$ mice show evidence of mesangial matrix expansion, a hallmark of diabetic nephropathy.
\end{abstract}

Leptin-deficient mice of the DBA- $o b$ strain have variable obesity-diabetes. In mice with high insulin $(>10 \mathrm{ng} / \mathrm{ml})$, DBA-ob/ob mice maintain their increased adiposity and have a large increase in betacell number. In mice with low insulin $(<1 \mathrm{ng} / \mathrm{ml})$ DBA-ob/ob mice have greatly diminished adiposity. These mice have atrophied islets with evidence of increased beta-cell neogenesis from the ductal epithelium.

Conclusions. The strain-specific responses suggest the existence of genetic variants that control insulin sensitivity and beta-cell responses in the strains described in this report. These new models of obesity-diabetes should prove useful in dissecting the genetic control of beta-cell responses to hyperglycaemia and insulin resistance. [Diabetologia (2002) 45:976-990]

Keywords Obesity, Type II diabetes mellitus, genetic modifiers, leptin receptor.
Obesity is usually associated with abnormalities in carbohydrate metabolism. In rodents with genetic perturbations of the leptin/leptin receptor system, the obese phenotype is associated with glucose intoler-

Received: 19 December 2001 / Revised: 12 March 2002 Published online: 6 June 2002

(C) Springer-Verlag 2002

Corresponding author: S. Chua Jr., MD, PhD, 1150 St. Nicholas Avenue, Room 628, New York, NY 10032, USA, E-mail: sc569@columbia.edu

Abbreviations: QUICKI, Quantative insulin sensitivity check index; LEPR, leptin receptor; LEP, leptin; GTT, glucose tolerance test; ITT, insulin tolerance test; $\mathrm{CHO}$-free, carbohydratefree. ance and varying degrees of insulin resistance [1]. The specific strain on which the mutation is maintained determines the response of the endocrine pancreas to hyperglycaemia and insulin resistance. Some strains, such as C57BL/6J and 129/J [2], have the ability to undergo compensatory hyperplasia of the pancreatic insulin producing cells with the resultant phenotype of near-euglycaemia due to hyperinsulinaemia. Some other strains (C57BLKS/J [3] and CBA/LtJ males [4]) respond poorly to the increased demand for insulin, they are unable to undergo the requisite compensatory responses, and show an end-stage diabetic syndrome of nearly complete beta-cell loss. A similar degree of variant diabetes phenotypes have been observed in rats with a leptin receptor deficiency on various inbred 
backgrounds: WKY [5], ZDF [6, 7], SHR [8], and LA [9]. In rats, it seems that only obese males are subject to developing severe hyperglycaemia and contraction of beta-cell numbers.

The loss of beta cells in these obesity-diabetes models is not mediated by the immune system. Studies have shown that C57BLKS/J $d b / d b(\mathrm{~K}-d b)$ mice develop their characteristic diabetes phenotype independent of a functional immune system [10]. The response of the beta cell in these obese rodents is subject to dietary influences. When placed on a completely carbohydrate-free diet (CHO-free diet), obese C57BLKS/J $d b / d b$ mice are able to maintain near-euglycaemia and preserve their pancreatic beta-cell mass [11].

While these strain-specific phenotypes have been documented [4], some of the congenic strains have been lost. This report describes the generation and characterisation of several new congenic mouse strains carrying mutations of Lep or Lepr. The FVB congenic strains (FVB- $d b$ and FVB- $o b$ ) provide a new diabetes phenotype that has not been described previously. Obese FVB mice suffer a prolonged period of hyperglycaemia that produces massive expansion of beta-cell mass. We show data that the early onset of severe insulin resistance probably accounts for the hyperglycaemia of these strains. The islet hyperplasia of obese FVB mice suggests that prolonged hyperglycaemia does not eventually lead to complete betacell atrophy, as it does in most models of diabetes. On the contrary, the phenotype of the obese FVB mice suggests that insulin resistance and hyperglycaemia could be the primary cause of beta-cell expansion. The FVB strain has a genetic constitution that would be useful in identifying the genetic determinants of beta-cell proliferation.

We also generated DBA congenic strains (DBA- $d b$ and DBA- $o b$ ). Obese mice of these strains suffer from hyperglycaemia due to a relative deficiency of beta cells and a dramatic loss of insulin secretory capacity. The associated lack of insulin action leads to severe body weight reduction. There is a certain degree of variability in the diabetic phenotype in obese DBA mice, with some obese mice maintaining neareuglycaemia. Hyperinsulinaemia is highly correlated with the maintenance of increased body weight and lower blood glucose concentrations. The obese DBA mice also suggest that early responses to hyperglycaemia and insulin resistance determine the eventual diabetes phenotype: compensatory hyperinsulinaemia leads to preservation of beta-cell mass while diminished insulin secretion coupled with hyperglycaemia eventually leads to the loss of insulin-producing cells.

\section{Materials and methods}

Congenic strain production. FVB/NJ and DBA/2J mice used for backcrosses were purchased from the JAX laboratories (Bar
Harbour, Me., USA). The FVB- $d b$ congenic strain was generated by introducing the Lepr ${ }^{d b}$ allele from C57BLKS/J- $m+/+d b$ repulsion stock. The FVB- $o b$ and DBA- $o b$ congenic strains were developed after introducing the $L e p^{o b}$ allele from the C57BL/6J-ob strain. The DBA- $m d b$ congenic strain was produced by introducing the Leprdb allele from the C57BL/6J- $m d b$ coupling stock purchased from JAX. The $d b$ [12] and $o b$ [13] mutations were tracked by direct PCR typing for the point mutations from ear clips. All congenic strains were backcrossed a minimum of 10 generations to the host strains. Each of the congenic strains were propagated from the progeny of a sib mating at the N10 generation. The mice were housed in ventilated cages with freely available food and water. The FVB congenic strains were maintained on a gamma-irradiated diet (PicoLab 5058, PMI Nutritional International, Richmond, Ind., USA) containing $9 \%$ fat by weight while the DBA congenics were maintained on a gamma-irradiated diet containing $4.5 \%$ fat (PicoLab 5053). These diets were chosen to mimic the diets provided by The Jackson Laboratories to their FVB/NJ and DBA/2J colonies (www.jaxmice.org). Litters were routinely weaned at 3 weeks of age. The mice were seronegative for all bacterial and viral pathogens tested. The mice were maintained in accordance with the applicable portions of the Animal Welfare Act and the United States Department of Health and Human Services "Guide for the care and use of laboratory animals".

Glucose and insulin tolerance testing. Glucose tolerance testing was done, using a dose of $1 \mathrm{mg} / \mathrm{g}^{0.75}$ of glucose injected intraperitoneally (i.p.) into mice that had been fasted overnight [14]. Insulin tolerance testing was carried out by injection of bovine insulin i.p. into fasted mice according to the doses indicated in the text. A previous report had indicated that $3 \mathrm{U} / \mathrm{kg}$ was necessary to induce a hypoglycaemic response in obese C57BLKS/J- $d b$ mice, a fourfold higher insulin concentration than for lean mice [15]. Tail blood (3 microliters) was collected for glucose determination by the glucose oxidase method (Glucometer Elite, Bayer, Elkhart, Ind., USA). Insulin concentrations in serum were measured by a commercial immunoassay using rat insulin as a standard (Linco, St. Louis, Mo., USA). Insulin values were converted to microUnits/ml using 6 microUnits $/ \mathrm{ml}$ being equivalent to $1 \mathrm{pmol} / 1$ and using a nominal molecular weight of 5700 for mouse insulin. The values for QUICKI [16] were calculated from fasted glucose and insulin concentrations based on the following formula:

QUICKI $=1 /(\log [$ glucose $]+\log [$ insulin $])$

Dietary manipulations. The carbohydrate-free diet was based on the AIN-93 diet [17] and prepared as a gel food using 1\% agar as a binding agent. Fasting was initiated by transferring mice to a clean cage with fresh bedding and water to minimise the ingestion of fecal pellets and to prevent the possibility of chow crumbs and powder being available in dirty bedding. All fasts were a minimum of $16 \mathrm{~h}$ overnight and tolerance tests were carried out between 9.00 am and 11:00 am.

Histopathology of pancreas and kidney. Pancreata and kidneys were dissected immediately after the mice were killed using carbon dioxide and fixed in formaldehyde (Bouin's solutions for pancreata and phosphate buffered formalin for kidneys). Tissues were processed and embedded in paraffin. Pancreatic sections (4 microns) were immunostained with a guinea pig anti-insulin antiserum and visualised with a commercial biotinylated rabbit anti-guinea pig-avidin-horseradish peroxidase conjugate using diaminobenzidine as the substrate. The number of insulin positive cells per cross section of an islet was 
calculated by counting the nuclei of DAB staining cells from a minimum of 12 islets per mouse (40 islets per genotype). The number of beta cells per islet was calculated from geometric considerations. Having been able to enumerate the number of nuclei per cross-section, we calculated the area of a circle (in units of cell nuclei). From the equations for the area of a circle $\left(r^{2} \pi\right)$ and the volume of a sphere $\left(4 / 3 r^{3} \pi\right)$, we can estimate the number of cells in a spherical islet for a given radius (number of cell nuclei). These estimates do not take into account volume changes that may occur in the individual beta cells, although our measurements are meant to measure relative cell numbers rather than absolute beta cell mass. Neogenic islets (islets containing less than eight insulin-positive cells) were not included. Kidney sections (2 microns) were stained with hematoxylin and eosin or for glycoconjugates with a periodic acid Schiff staining procedure.

Statistical analysis. Groups were compared by use of nonparametric tests (Mann-Whitney U-test and paired sign test) with significant differences set for a $p$ value of less than 0.05 . For data sets with more than 20 data points per group, the data were analysed using the Student's $t$ test with significant differences set for a $p$ value of less than 0.05 .

\section{Results}

The obese FVB-db mouse has chronic hyperglycaemia and insulin resistance. We generated the FVB.C57BLKS-Lepr $d b$ (F- $d b$ ) mouse strain by ten serial backcrosses of the diabetes mutation from the $\mathrm{C} 57 \mathrm{BLKS} / \mathrm{J}-m+/+d b(\mathrm{~K}-d b)$ congenic strain to FVB/NJ mice [18], aided by direct detection of the $d b$ point mutation. We compared the diabetes syndrome of two congenic strains that we have developed, the FVB- $d b$ strain and the B6- $d b 3 J$ strain. The B6- $d b 3 J$ strain has been described and has the same characteristics of the B6- $d b$ congenic strain, despite the differences in the nature of the two mutations.

Obese FVB mice of both sexes have a prolonged period of hyperglycaemia of several months at least, in the fed state (Fig. 1). This is in contrast to the more commonly used obese B6 mice (both B6- $d b$ and B6- $d b 3 J$ congenic strains), where the blood glucose concentration rarely rises above $250 \mathrm{mg} / \mathrm{dl}$ (Fig. 1). Nevertheless obese mice of the two strains attain similar body weights (Fig. 1A,B). Measures of circulating insulin in the fed state show that the obese FVB mice have extreme insulin resistance. A prospective study indicates that the phenotype develops as the mice age (Fig. 1E, F). At 3 months of age, insulin concentrations are similar between obese male mice of the FVB and B6 strains, although obese FVB females show a trend (not significant) toward higher values than obese B6 female mice. The insulin concentrations of the obese FVB mice continues to increase at 5 and 7 months of age, attaining $\sim 40 \mathrm{ng} / \mathrm{ml}$ for obese male mice (not different from obese B6 males) and $\sim 500 \mathrm{ng} / \mathrm{ml}$ for obese female $(p<0.01$, obese FVB females are different from obese B6 females at 5 and 7 months of age). The difference between the male


Fig. 1A-F. General characteristics of the FVB- $d b$ and B6- $d b 3 J$ congenic strains. Body weights of obese male (A) and obese female mice (B) of the FVB-db (open diamonds for males and open circles for females with symbols connected by solid lines) and B6-db3J (filled diamonds for males and filled circles for females with symbols connected by dashed lines) strains. Blood glucose concentrations $(\mathbf{C}, \mathbf{D})$ and serum insulin concentrations in the fed state are shown for the same animals. For comparisons, we have included the data from 1-month-old B6 $d b / d b$ mice, represented by grey symbols (diamond for males and circle for females) The symbols represent the means and standard deviations from groups of 4 to 8 mice. ${ }^{*} p<0.05$, (MannWhitney test) between the strains

and female obese FVB- $d b$ mice is not unusual and is consistent with the gender dimorphism in diabetes susceptibility observed in most mouse strains.

We have also documented the glucose and insulin concentrations in the fasted state in obese mice of the two strains (Table 1 ). While fasting brings the blood glucose concentrations of the obese B- $d b 3 J$ mice to the euglycaemic range, the obese F- $d b$ mice are hyperglycaemic at 3 months of age. There is a gradual improvement in glycaemic status in the obese F- $d b$ mice as they age, along with increasing fasting insulin concentrations. The alterations in glucose and insulin concentrations can be readily interpreted by the presence of severe insulin resistance. We have used a measure of insulin sensitivity, QUICKI, that correlates closely with 
Table 1. Insulin resistance in fasted FVB- $d b / d b$ and B6- $d b 3 J / d b 3 J$ mice

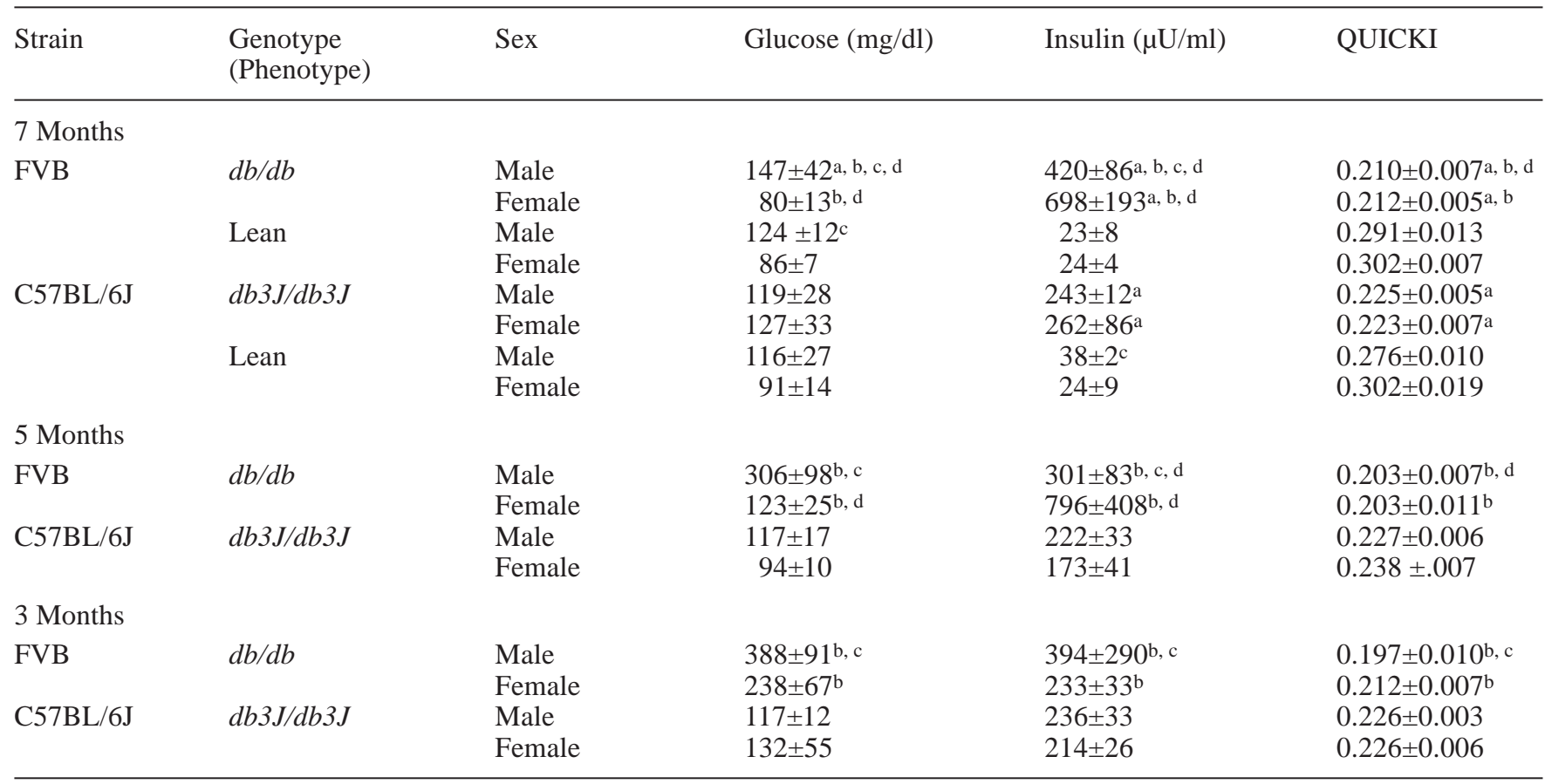

Fasting glucose and insulin concentrations are shown for lean and obese mice of both sexes and both strains at three ages. Insulin concentrations are shown in $\mu \mathrm{Units} / \mathrm{ml}$ for the presentation of the QUICKI. The data are shown as means with standard deviations a A significant difference due to the Lepr mutations (obese vs lean within a strain, same sex comparison) while a caret

b A significant difference due to an interaction between the Lepr mutations and strain (obese vs obese between strains, same sex comparison)

$\mathrm{S}_{\mathrm{I}}$ in human glucose clamp studies. Since QUICKI incorporates both insulin and glucose concentrations, it provides a single value for evaluation of insulin sensitivity. For all strain and sex combinations, the LEPRdeficient state causes insulin resistance, as shown by a decreased QUICKI value. In accord with the metabolic parameters in the fed state, obese F- $d b$ mice of both sexes have a lower QUICKI value than obese B- $d b 3 \mathrm{~J}$ mice, signifying increased insulin resistance.

Increased insulin secretion and increased beta-cell mass in obese FVB-db mice. The drive to increase circulating insulin concentrations of the obese F- $d b$ mice is probably due to severe insulin resistance and attendant hyperglycaemia. Although we do not know of the cause of the insulin resistance, we have documented its development in obese F- $d b$ mice. Glucose tolerance testing of young (6-week-old) mice of both F- $d b$ and B6- $d b$ indicate no differences in glucose tolerance between lean mice of the two strains (Fig. 2). Obese mice of both strains show abnormal glucose tolerance curves, with a rapid increase of blood glucose above $400 \mathrm{mg} / \mathrm{dl}$ followed by a diminished rate of glucose clearance (Fig. 2). There were no strain differences in glucose tolerance between obese mice at this age. Ten c Differences due to sex within the same strain or genotype d An age effect (comparison between groups of same strain or genotype or sex, using the groups at 3 months for comparison) Note that there are no sex differences between groups of the same genotype or strain for QUICKI. Significant differences $(p<0.05)$ were determined with a two-way Students $t$ test

days later, we carried out an insulin tolerance test on a subset of the same mice used for the GTT (Fig. 2). At a dose of $3 \mathrm{U} / \mathrm{kg}$, the obese F- $d b$ mice (both sexes) showed a diminished response to insulin relative to obese B6- $d b$ mice. There is a large variability in the responses of obese F- $d b$ female mice such that we were unable to show a significant response to insulin although there were clear examples of individual females that responded to insulin. These data indicate that increased insulin resistance is the primary phenotype that distinguished obese F- $d b$ mice from obese B6- $d b$ mice, as suggested by comparisons of the QUICKI values for obese mice of the two strains.

At 7 months of age, we observed a clear difference in the glucose tolerances of obese mice of the two strains, with clear sexual dimorphism in the obese F- $d b$ mice (Fig. 3). Obese F- $d b$ males are severely glucose intolerant, having glucose values of more than $400 \mathrm{mg} / \mathrm{dl}$ at $90 \mathrm{~min}$ after the glucose load. Obese F- $d b$ females have a glucose tolerance curve that is not different from lean mice, presumably due to their extremely high circulating insulin concentrations (Fig. 1 and Table 1 ). Obese B6- $d b 3 J$ mice have a peak of glucose between 40 and $60 \mathrm{~min}$ and are obviously clearing the glucose load by $90 \mathrm{~min}$. There are 



Fig. 2A-D. Hyperglycaemia of young obese F- $d b$ mice and severe insulin resistance. A, B Abnormal glucose tolerance of young obese F- $d b$ and B6- $d b$ mice. Fasted mice were injected with isotonic glucose. Glucose was monitored from tail blood at the prescribed intervals. The symbols represent the means of 4 to 8 mice in each group between 6 to 7 weeks of age. For reference purposes, we have included the data for lean FVB and lean B6 mice using the same lines (solid for FVB and dashed for B6) without the symbols. There are no significant differences between lean mice of the two strains or between obese mice of the two strains at this age. An asterisk (*) represents a significant difference $(p<0.05$, Mann-Whitney test) between lean and obese mice of the same strain. C, D Differential insulin sensitivity between obese F- $d b$ and B6- $d b$ mice. Fasted mice were injected with bovine insulin in sterile saline. A subset of the mice from Fig. 2A and $2 \mathrm{~B}$ were used (three mice in each group, 7-8 weeks of age). The blood glucose values are shown as a percent of the starting glucose concentrations for individual mice. Symbols are as in Fig. 1. An asterisk (*) represents a difference from T0 $(p<0.05$, paired sign test). A caret $(\wedge)$ represents a difference between strains at a given time point $(p<0.05$, paired sign test)

no differences in the glucose tolerances between lean mice of the two strains (Fig. 2).

It is possible that the obese F- $d b$ mice have increased insulin concentrations of a biologically inactive form of insulin, perhaps due to improper process-


ing within the beta cell or proteolytic cleavage after secretion although it has been shown that insulin extracted from the pancreata of $\mathrm{B}-o b / o b$ mice is biologically equipotent to insulin from lean mice [19]. To exclude this possibility, we carried out insulin tolerance tests on fasted obese F- $d b$ and B6- $d b 3 J$ mice (Fig. 4) at 7 months of age. A dose of $3 \mathrm{U} / \mathrm{kg}$ did not cause any drop in circulating glucose concentrations of F- $d b$ mice of either sex while obese B6- $d b 3 \mathrm{~J}$ mice (both males and females) showed a 50\% drop in glucose concentrations by $40 \mathrm{~min}$. This lack of response in obese F- $d b$ mice indicates that the obese F- $d b$ mice become more insulin resistant over time since a similar insulin dose at 2 months of age was able to cause a drop of glucose in obese F- $d b$ male mice. To show increased insulin resistance in these older mice, we used a fourfold higher dose of $12 \mathrm{U} / \mathrm{kg}$ in the obese F- $d b$ mice. This higher dose of insulin caused a drop of blood glucose by $40 \mathrm{~min}$ in obese FVB males. The higher $12 \mathrm{U} / \mathrm{kg}$ dose of insulin still did not cause a decrease of blood glucose in obese F- $d b$ females. This is not surprising given that endogenous insulin concentrations of $500 \mathrm{ng} / \mathrm{ml}(\sim 200-500$ times higher than lean mice) are not able to achieve euglycaemia in the obese F- $d b$ female mice, given that the $12 \mathrm{U} / \mathrm{kg}$ dose is only 16-fold higher than the effective insulin dose in lean animals. 

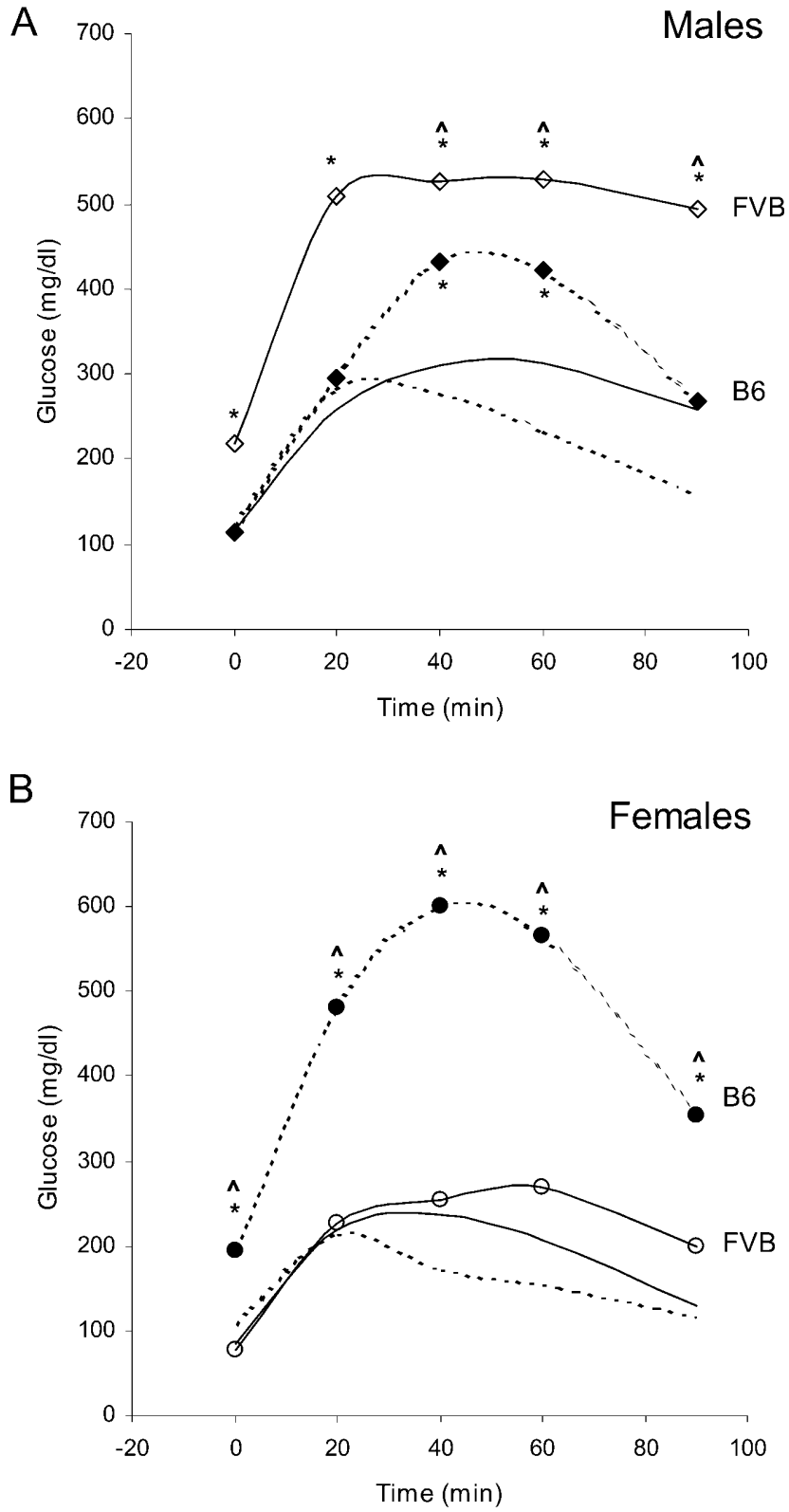

Fig. 3A, B. Glucose tolerance of obese F- $d b$ and obese B6- $d b 3 J$ mice at 7 months of age. A, B The GTT was carried out as described in the Methods section. The symbols represent the means of four to six mice in each group. The obese FVB mice are represented (open diamonds for males and open circles for females, with symbols connected by solid lines). The lean FVB mice are represented by solid lines without symbols. The obese B6 mice are represented (filled diamonds for males and filled circles for females, with symbols connected by dashed lines). Lean B6 mice are represented by dashed lines without symbols. An asterisk (*) indicates a difference between obese and lean mice of the same strain $(p<0.05)$. A caret $\left({ }^{\wedge}\right)$ represents a strain difference between obese mice $(p<0.05)$. Comparisons were done with the Mann-Whitney U test

We examined the pancreatic islets of obese F- $d b$ mice (Fig. 5). Histological sections stained for insulin immunoreactivity indicated massive expansion of the beta cells in obese FVB mice (means of insulinpositive cells per islet cross-section: lean $=165$ vs


Fig. 4A-D. Differential progression of insulin resistance between F- $d b$ and B6- $d b^{3 J}$ mice. Insulin was injected at $3 \mathrm{U} / \mathrm{kg}$ (FVB- $d b$ and B6- $d b 3 J$ mice; A for males and B for females) and $12 \mathrm{U} / \mathrm{kg}$ (FVB mice only, $\mathbf{C}$ for males and $\mathbf{D}$ for females). The values are normalised to $100 \%$ at $\mathrm{T} 0$ for each mouse. The symbols represent the means for four to nine mice. Symbols follow the convention in Fig. 3. An asterisk $(*)$ represents a significant difference $(p<0.05)$ from T0. A caret $(\wedge)$ represents a significant difference between strains. Pairwise comparisons to test for insulin effects were carried out with the sign test. Interstrain comparisons were done with the Mann-Whitney U test

obese $=744, n=40$ islets for each genotype), accounting for the tremendous increase in circulating insulin concentrations. We counted 4.5 times more cells per islet cross section in the pancreas of obese mice than in lean mice. The estimate of about 4.5 times more cells, based on a cross-sectional area, was an underestimate of differences in beta-cell number since beta-cell numbers should be considered using volumes. Using geometrical arguments, we estimated that the islets of obese F- $d b$ mice have approximately ninefold more cells than the islets of lean mice. The distribution of islet sizes indicated that the increase in islet-cell number was due to intra-islet expansion, producing a class of islets with more than 1000 cells per cross section, that were not present in lean mice. This size class of islet represented all of the increase in beta-cell number in obese mice. The beta-cell mass expansion could occur from proliferation of existing beta cells or from recruitment of pre-beta cells to existing islets; however, these possibilities have yet to be distinguished.

Hyperglycaemia of obese F-db mice is maintained from dietary and non-dietary sources. We reasoned that the glucose source that maintains the high glucose 
A

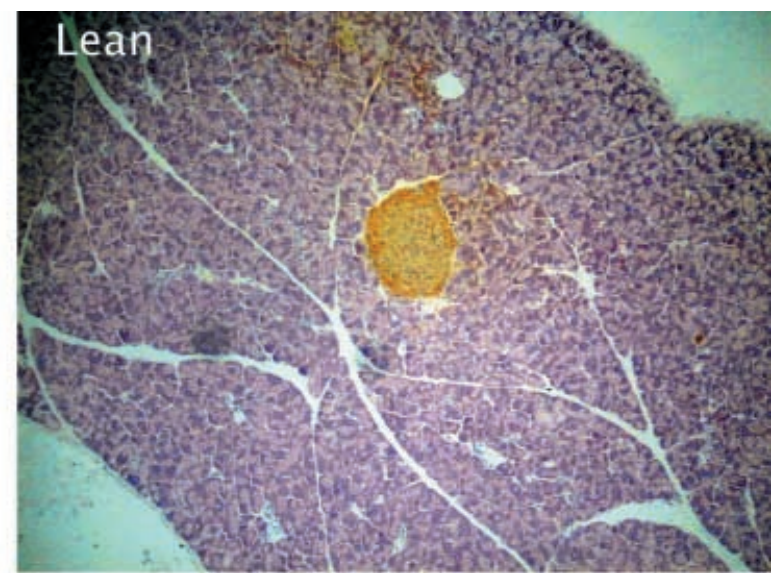

B
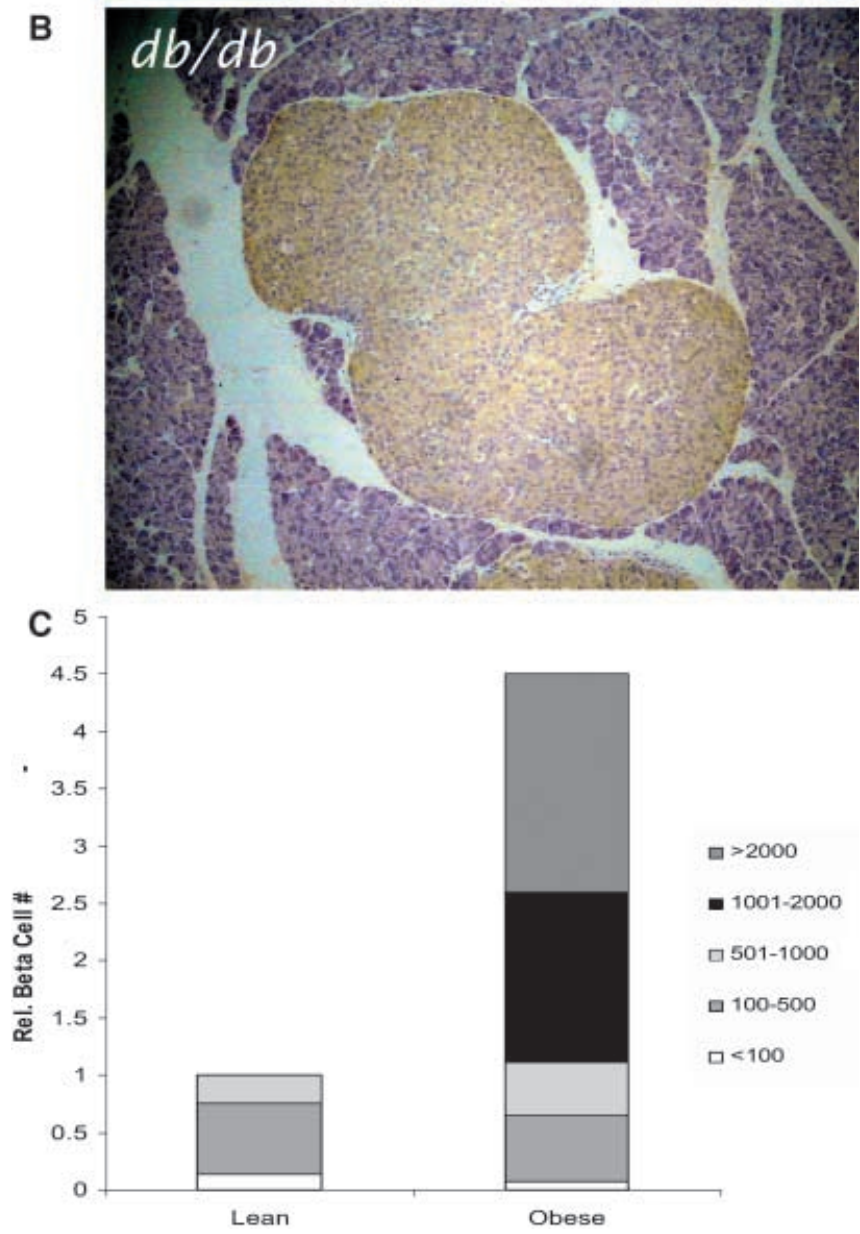

Fig. 5A-C. Massive expansion of pancreatic beta cell mass in obese FVB mice. Pancreatic sections from obese F- $d b(\mathbf{A})$ and lean (B) mice were immunostained with guinea pig anti-insulin antibodies followed by a commercial rabbit anti-guinea pig IgG (Vector Laboratories, Burlingame, Calif., USA). Sections were imaged at $\times 100$. (C) Relative numbers of insulin positive cells per islet in the pancreata of lean and obese mice. Islets were classified according to number of insulin-positive cells per cross sectional area of an islet and the mean islet cell area (numbers of cells) for three lean female mice were set to 1.0. The mean islet cell area of three obese FVB female mice was calculated relative to the lean animals. The bars are subdivided into the relative contributions from islets containing a range of insulin-positive cells
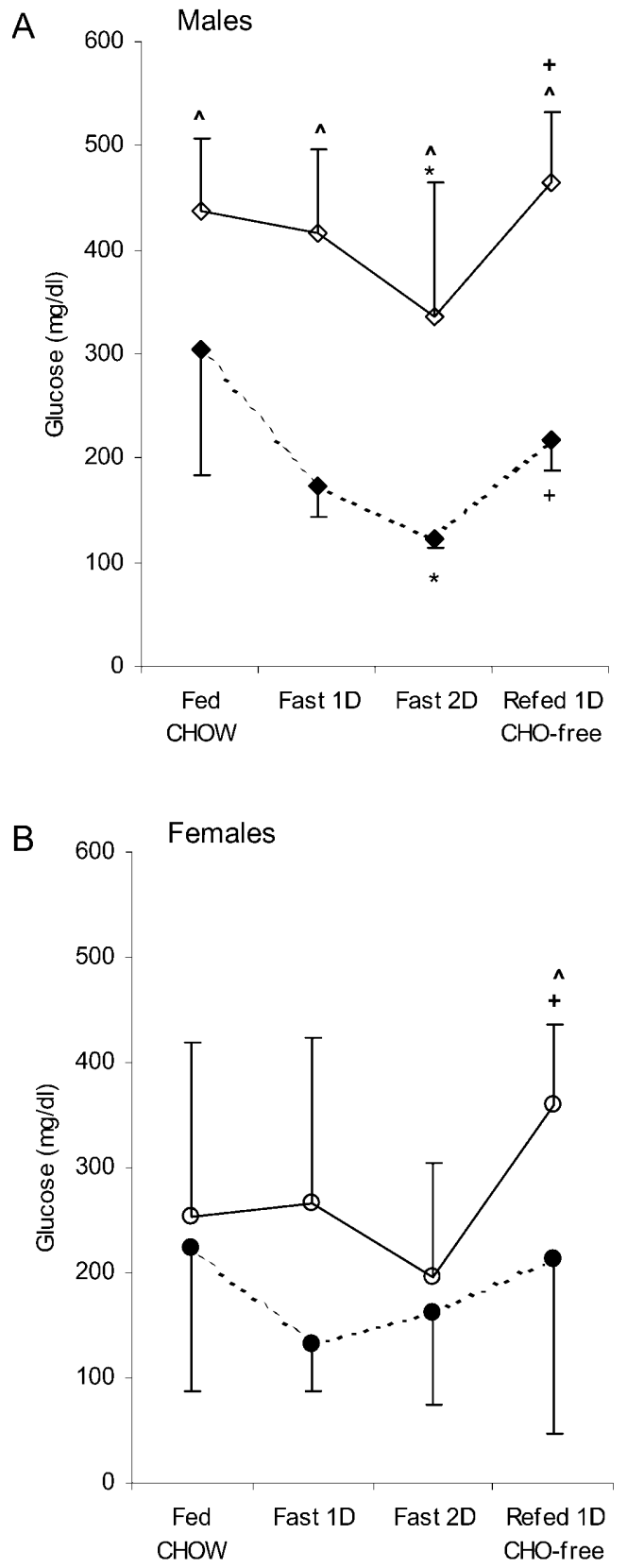

Fig. 6. Hyperglycaemia maintained by non-dietary carbohydrate sources in obese FVB mice. Two month old obese mice (FVB- $d b$ and B6-db3J) had their blood glucose monitored while feeding on rodent feed, while fasting (1 day and 2 days), and after being re-fed a carbohydrate-free feed (20\% protein, $80 \%$ corn oil) for 1 day. The symbols represent the means and standard deviations for four to nine mice in each group, following the convention of Fig. 1. An asterisk $(*)$ represents a significant difference $(p<0.05)$ from the chow-fed state. A plus $(+)$ represents a significant difference $(p<0.05)$ from the 2 -day fasted state. A caret $(\wedge)$ represents a strain difference $(p<0.05)$. Pairwise comparisons of feeding status were done with the sign test while interstrain comparisons were done with the Mann-Whitney U test

concentrations of the obese $d b / d b$ mice could be derived from two sources: diet and endogenous stores. We again fed 2-month old obese FVB mice and obese B6 mice a carbohydrate-free diet for 1 day, after a 2-day fast (Fig. 6). We decided to use 2-month old 


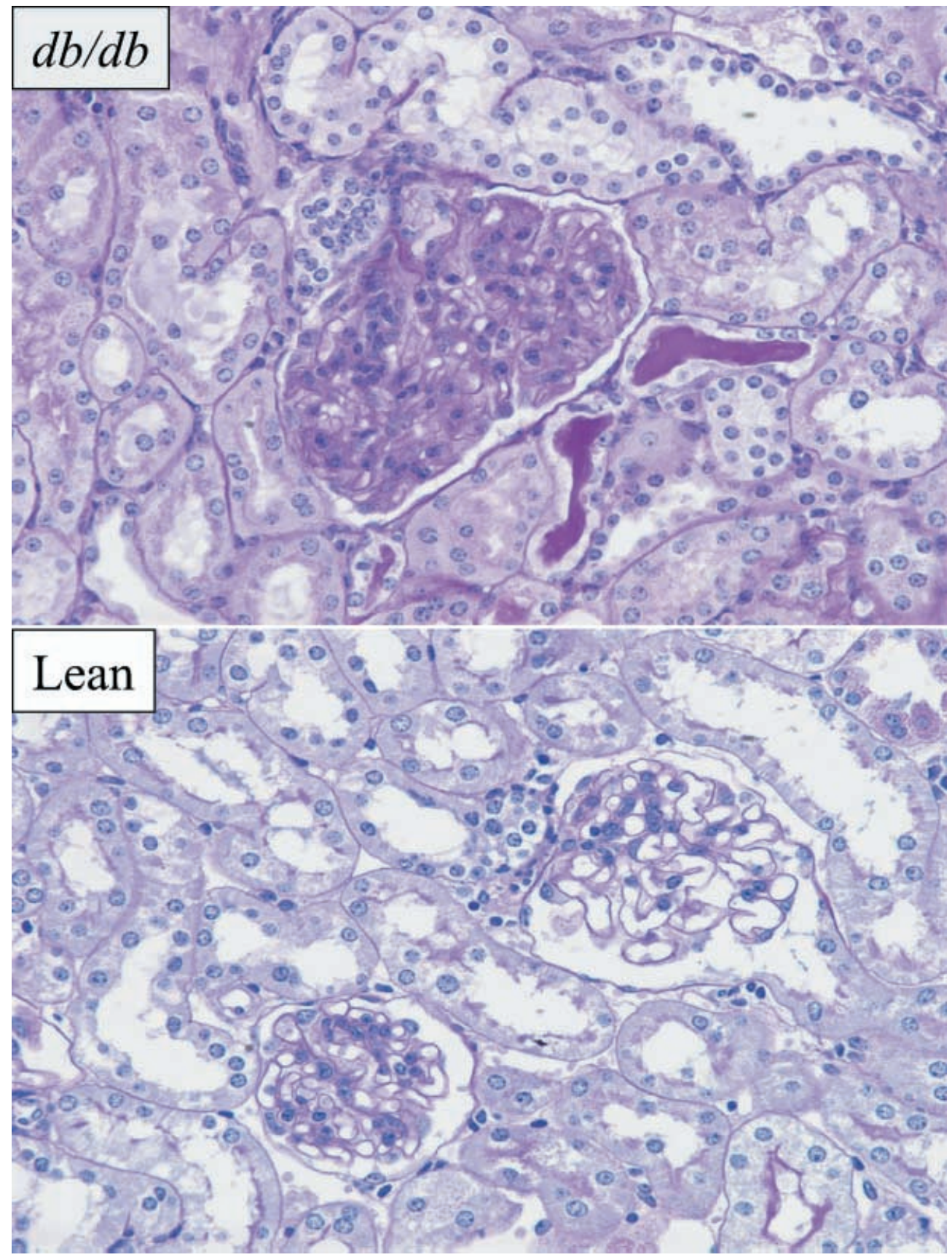

Fig. 7A, B. Glomerular lesions in F- $d b$ mice with long-term hyperglycaemia. Kidney sections were stained with periodic acid Schiff. Glomeruli of hyperglycaemic and obese F- $d b$ female mice show mesangial matrix expansion (A) compared to lean, normoglycaemic controls $(\mathbf{B})$. Sections are shown at $\times 400$

mice to minimise the effects of prolonged hyperglycaemia and hyperinsulinaemia although it is clear that it is impossible to match obese mice of the two strains for all metabolic parameters (Fig. 1). The 2-day fast was necessary to observe a decrease in glucose concentrations in obese B6 mice and obese FVB male mice. The obese female mice of both strains did not show a decrement in blood glucose even after a 2-day fast, indicating that the dietary carbon was not the primary source for maintaining the hyperglycaemic state.

To test the contribution of dietary carbohydrate to the hyperglycaemic state of the obese mice, the mice were again fed a carbohydrate-free (CHO-free) diet wherein all of the carbohydrate components were replaced with corn oil. The obese F- $d b$ male and obese B6- $d b$ male mice have blood glucose concentrations on the $\mathrm{CHO}$-free diet that rose above the fasted state and are not different from their blood glucose values on standard feed (Fig. 6A). In all feeding states, the obese FVB male mice maintain a higher blood glucose concentration than the obese B6 male mice. 
The obese FVB female mice showed a rise in blood glucose above the 2-day fasting blood glucose concentrations upon refeeding the $\mathrm{CHO}$-free diet (Fig. 6B). This increase in blood glucose after refeeding was not observed in obese B6 female mice. These observations, suggest that there is a strain difference in the metabolic handling of carbohydrates (from the diet and from endogenous sources) that is responsible for the hyperglycaemic state of obese FVB mice.

Obese FVB mice exhibit diabetic nephropathy. The glomeruli of obese FVB mice at 7 months of age and older showed changes reminiscent of diabetic nephropathy (Fig. 7). Most of the glomeruli in obese mice showed an increased mesangial matrix. None of these morphological changes were seen in age-matched lean mice. There were occasional glomeruli that showed sclerosis - small glomeruli that had separated from the capsule with nearly obliterated microtubules. Measurements of plasma creatinine and blood urea nitrogen, however, did not show any differences between lean and obese F- $d b$ mice, suggesting that the morphological changes were insufficient to produce a functional impairment of the kidney. Long-term hyperglycaemia in obese FVB- $d b$ mice results in histopathological changes but not functional changes in the kidney that mimic the changes observed in human diabetic nephropathy.

A diabetes syndrome of hyperglycaemic hyperinsulinaemia in obese F-ob mice. We have generated another congenic FVB strain carrying the Lep ${ }^{o b}$ mutation (FVB.C57BL/6J-Lep ${ }^{o b}$ or F-ob). The $o b$ mutation was transferred from the standard C57BL/6J-ob congenic strain after ten generations of backcrossing to FVB/NJ mice. We measured fed glucose and insulin concentrations of the obese F-ob animals (Table 2 ) and we observed the hyperinsulinaemic hyperglycaemia syndrome that characterised the obese $\mathrm{F}-d b$ mice. Although we have not done extensive testing of this congenic strain, it is most likely that these mice will exhibit a diabetes syndrome that is similar, if not identical, to the obese F- $d b$ mice.

Variable obesity-diabetes phenotype in obese DBA-ob mice. We were interested in observing the diabetes phenotype in obese DBA mice since the DBA strain is the presumed contaminating strain that contributes to the diabetes-susceptibility alleles of the C57BLKS strain. Although we have generated two congenic strains (DBA- $o b$ and DBA- $d b$ ) on the DBA/2J host strain, we only show data on the DBA- $o b$ congenic strain. We did a cross-sectional survey of the diabetes phenotype of obese DBA-ob mice by measuring body weights, blood glucose and insulin concentrations. We observed that there was a great variability in the obesity-diabetes phenotypes that seemed to be independent of sex. The data that are shown below represent
Table 2. Glucose and insulin concentrations of obese F-ob mice. The data are shown as means of the groups along with their standard deviations. The data were collected from mice at the N8F1 generation

\begin{tabular}{lllll}
\hline & $n$ & $\begin{array}{l}\text { Age } \\
(\text { months })\end{array}$ & $\begin{array}{l}\text { Glucose } \\
(\mathrm{mg} / \mathrm{dl})\end{array}$ & $\begin{array}{l}\text { Insulin } \\
(\mathrm{ng} / \mathrm{ml})\end{array}$ \\
\hline Male mice & 16 & $3.0 \pm 1.2$ & $574 \pm 60$ & $19.9 \pm 10.4$ \\
Female mice & 21 & $3.3 \pm 1.1$ & $388 \pm 104$ & $46.9 \pm 32.1$ \\
\hline
\end{tabular}

73 animals rather than serial measures on a small group as the animals' age.

There is a large scatter of body weights for the $o b / o b$ DBA mice (Fig. 8). The large majority of the obese DBA mice attain a peak body weight and subsequently start to lose body weight. The loss of weight is sometimes so severe that the $o b / o b$ mice of the DBA- $o b$ congenic strain weigh less than their wildtype siblings (Fig. 8), where lean male mice have a mean body weight of $30.5 \mathrm{~g}$ and lean female mice have mean weights of $26.9 \mathrm{~g}$ (at an average age of 4 months). We have not been able to find any effect of sex on the ability of some obese DBA-ob mice to maintain increased insulin secretory capacity. It is possible to arbitrarily assign a cut-off point of about $10 \mathrm{ng} / \mathrm{ml}$ for insulin concentrations at which insulin secretory capacity is maintained in obese DBA- $o b$ mice (Fig. 9). There is excellent correlation between low body weights and hyperglycaemia to insulin concentrations below $10 \mathrm{ng} / \mathrm{ml}$ whereas high body weights and near-euglycaemia are correlated with insulin concentrations above $10 \mathrm{ng} / \mathrm{ml}$.

Responses of the beta cell to insulin resistance in obese DBA-ob mice. We carried out histological examinations of the pancreas of normal and mutant $(o b / o b)$ DBA mice. In the pancreata of the mutant mice that had high circulating insulin concentrations (>10 ng/ml), we observed a large expansion of the beta cells (Fig. 9). The mutant mice had a mean of 563 insulin-positive cells per islet cross section compared to a mean of 193 cells per islet cross section for lean mice, representing a 2.9-fold increase of cells per unit area. There was no difference in the mean beta-cell numbers per cross-sectional-islet area between lean mice of the DBA and FVB strains $(\mathrm{DBA}=193$ and $\mathrm{FVB}=165$ ). When calculating the numbers of cells per islet, we estimated that there was a fivefold increase of insulin-secreting cells per islet of the obese mice. This increase was mainly in the class of islets that contain more than 500 insulin-positive cells per islet cross section.

In contrast to the beta cell expansion of DBA- $o b$ mice with high circulating insulin concentrations, the DBA- $o b$ mice with low insulin concentrations (typically $<1 \mathrm{ng} / \mathrm{ml}$ ) have very few islets that have greater than 20 insulin positive cells. The extremely low in- 

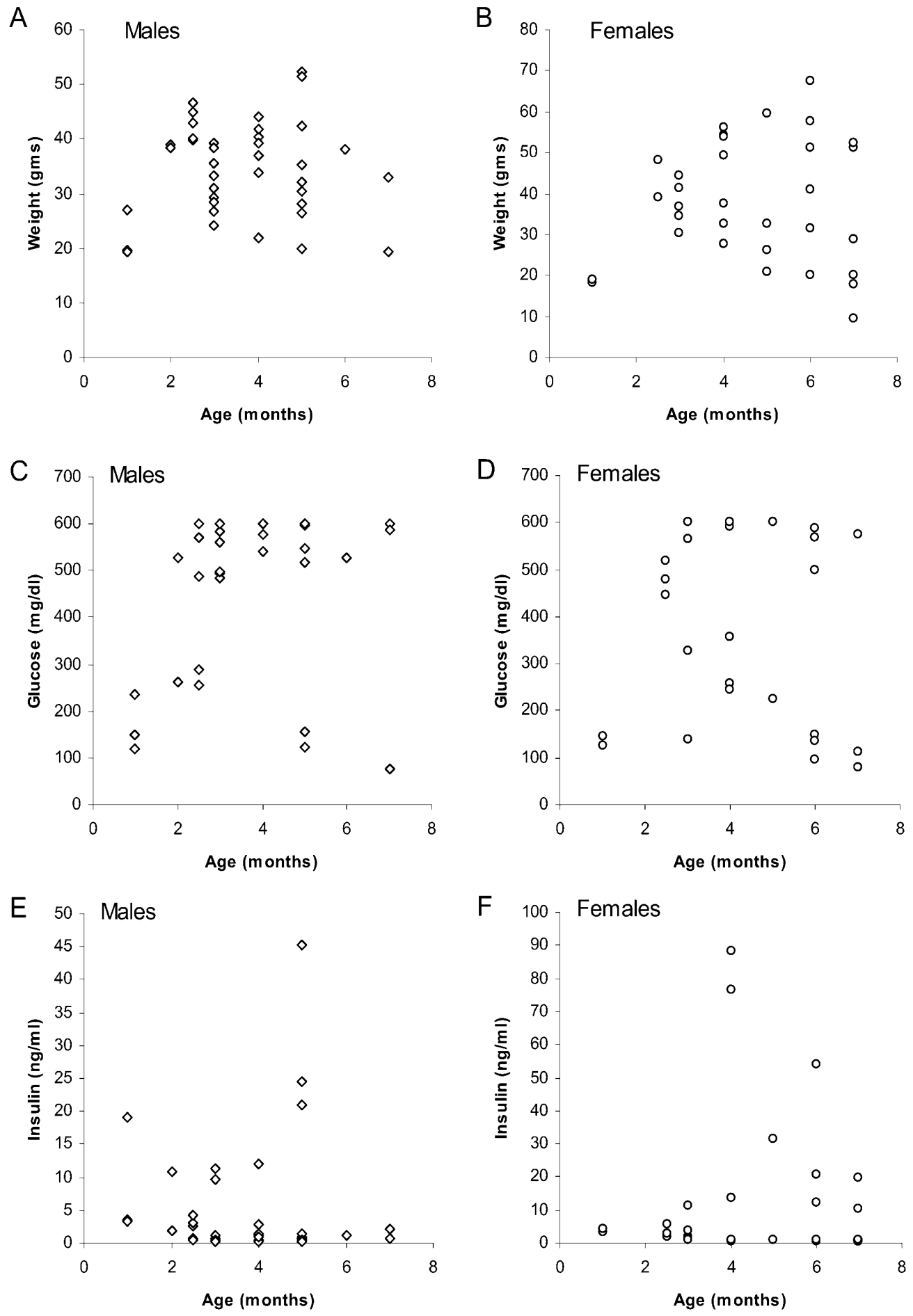

Fig. 8A-F. General characteristics of obese DBA- $o b$ mice. Body weights (A, B), blood glucose concentrations $(\mathbf{C}, \mathbf{D})$, and serum insulin concentrations $(\mathbf{E}, \mathbf{F})$ are shown for individual mice, according to their ages. Data for individual males (diamonds) and females (circles) are shown

sulin concentrations and impoverished beta-cell numbers of the low insulin DBA-ob mice, in the context of extreme hyperglycaemia, precluded any meaningful comparisons of insulin secretion between the low and high insulin DBA-ob mice. We were unable to

carry out a quantitative analysis due to the paucity of recognisable islets. We would not have been able to identify most of the beta cells without the immunochemical stain due to the untypical appearance of the islets. Most of the insulin-staining cells were found in small clusters of one to four cells and in scattered clusters within ductal epithelium. The cells in the ductal epithelium are probably evidence of neogenesis of beta cells and recruitment of insulin-secreting cells from a beta-cell precursor. We have not observed insulin-staining cells in the ducts of lean mice, 


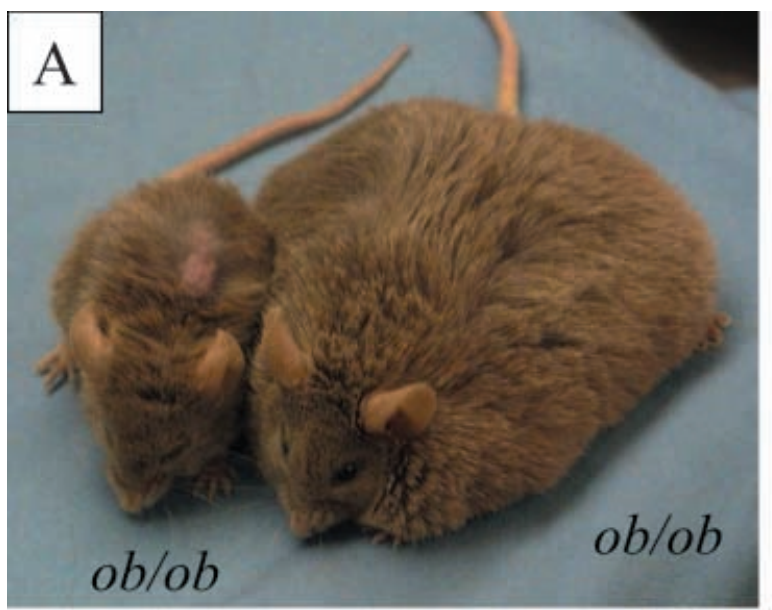

B
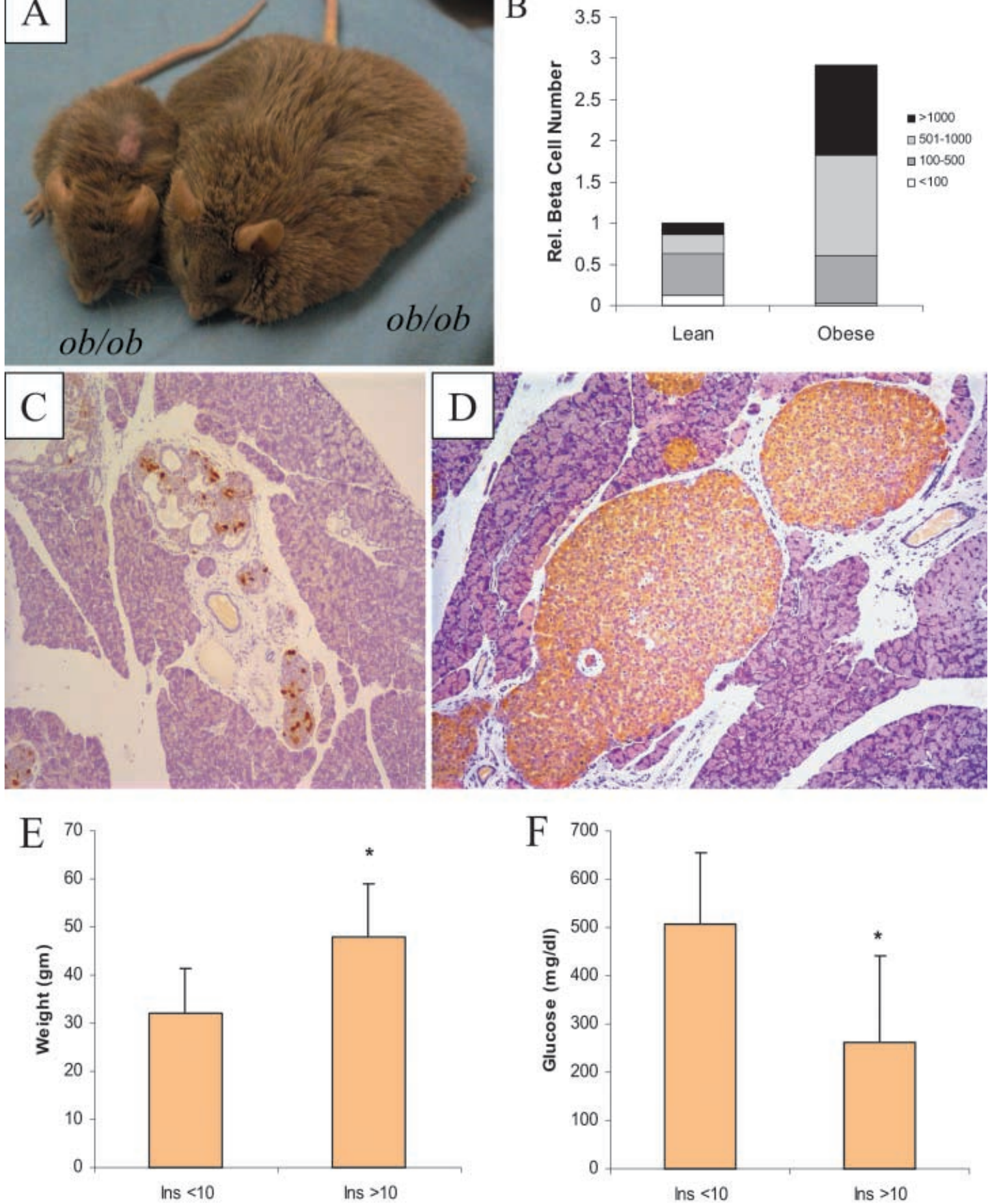

Fig. 9A-F. Phenotypic variability of DBA- $o b$ mice. (A) Two littermate $o b / o b$ mice are depicted, showing the extremes of body weights. The two mice are $\sim 6$ months old - the mouse on the left typifies the DBA-ob mouse that loses weight and has very low circulating insulin concentrations while the mouse on the right typifies the type that continues to gain weight and maintains hyperinsulinaemia. (B) Quantification of the expansion of beta cells in DBA-ob/ob mice with increased serum insulin concentrations $(>10 \mathrm{ng} / \mathrm{ml})$. Relative islet cellularity is based on counting individual insulin-staining cells in 40 islets for each genotype and calculated as in Fig. 5. (C, D) Islets from two DBA- $o b$ mice. The islets in $(\mathbf{C})$ are representative of the pancreas from an $o b / o b$ mouse that is hyperglycaemic, has

lost significant body weight and has a serum insulin concentration $<1 \mathrm{ng} \cdot \mathrm{ml}$. Note that a minority of the cells in any islet is insulin-positive. The islets in $(\mathbf{D})$ are representative of the pancreas from an $o b / o b$ mouse that is nearly euglycaemic, has maintained an increased body weight, and has a serum insulin concentration $>20 \mathrm{ng} / \mathrm{ml}$. Sections were imaged at $\times 100$. (E, F) A cut-off of $10 \mathrm{ng} / \mathrm{ml}$ of insulin is highly correlated with body weight and glucose concentrations. Animals were classified according to their serum insulin concentrations. Body weights (E) and glucose concentrations (F) between the high and low insulin groups were compared. An asterisk (*) indicates a significant difference between the high and low insulin groups ( $p<0.01$, one-sided Students $t$ test) 
nor have we observed insulin-positive cells in the ductal epithelium of obese mice with increased circulating insulin concentrations in the $\mathrm{B} 6, \mathrm{FVB}$ or DBA strains.

\section{Discussion}

Modifiers of the obesity-diabetes syndrome. Others have recognised that two mutations, Lep-ob and Lepr-db, produce identical phenotypes that are dependent on strain background. Many experimental manipulations have been documented that ameliorate each of the cardinal features of the two mutations: (i) hyperphagia; (ii) obesity; (iii) diminished non-shivering thermogenesis (NST); (iv) infertility; (v) preferential fat deposition, and (vi) diabetes. Hyperphagia and concomitant obesity is abetted by pair-feeding as well as the loss of adrenal steroids via adrenalectomy [20]. All aspects of the obesity-diabetes syndrome of LEP-deficiency can be corrected by leptin treatment [21]. Almost all aspects of the obesity-diabetes syndrome of LEPR-deficiency are ameliorated by neuron-specific expression of LEPR [14]. Obesity is diminished by a partial block to adipocyte differentiation via knockouts of genes required for adipogenesis [22]. The loss of NPY in obese $(o b / o b)$ mice reduces hyperphagia as well as obesity [23]. The impairment of BAT activation and NST is relieved by prior exposure of the mice to a cool environment (140C) for a prolonged interval [24]. Infertility is improved on mixed genetic backgrounds and up to $50 \%$ of obese male mice can be fertile in outcrosses of the standard B6 congenics to BALB/c [25]. Treatment with an adrenal steroid, dehydroepiandrosterone (DHEA) reduces fat accumulation [26].

Many experimental manipulations are known to modify the diabetes of obese $o b$ and $d b$ mice. Genetic manipulations, such as the introduction of a musclespecific GLUT4 transgene, dramatically improve glucose tolerance although diabetes is not completely corrected [27]. Hormonal manipulations, such as adrenalectomy [28] and treatment with thiazolidinediones [29], can also improve glucose tolerance and insulin sensitivity. Manipulation of the diet, so that all carbohydrates are replaced with protein, also can bring about an improvement in glycaemic control [11].

Our results with the obese FVB and DBA mice indicate that insulin resistance and beta-cell proliferation are probably influenced by genetic factors. This would suggest that it might be possible to identify the genes and their alleles that modulate leptin-related insulin resistance and beta cell proliferation. As humans with LEP or LEPR deficiency are not overtly diabetic, it is difficult to extrapolate our findings regarding insulin resistance to potential human applications.

Genetic modifiers of diabetes susceptibility. The genetic factors that modulate beta-cell proliferation in
FVB, DBA, and B6 mice should have implications relevant to human biology. Both FVB and B6 obese mice compensate for insulin resistance by expanding beta-cell mass whereas obese mice of the C57BLKS strain seem unable to compensate and lose insulin secretory capacity in a dramatic manner over a few short months. In particular, it would be of great interest to identify the factor(s) responsible for differential betacell survival and proliferation in the FVB and C57BLKS strains.

Our rationale for testing the FVB strain as a host for congenic strain production was to identify a new model of obesity-diabetes that is characterised by persistent hyperglycaemia and extreme insulin resistance. Previous studies had indicated that most strains that carry either the $o b$ or the $d b$ mutations have one of two major diabetes phenotypes: (i) transient hyperglycaemia followed by near euglycaemia and hyperinsulinaemia (exemplified by the C57BL/6J congenic strains) or (ii) persistent hyperglycaemia and early mortality due to loss of beta-cell mass (exemplified by the C57BLKS/J congenic strains). Some transgenic studies have indicated that FVB mice that become obese or are leptin deficient develop a syndrome of severe hyperglycaemia and extreme insulin resistance $[30,31]$. This suggested that it is possible to have prolonged hyperglycaemia and maintain hyperinsulinaemia. Loss of pancreatic beta-cell mass is not an inevitable outcome of prolonged hyperglycaemia. Since strain differences are most likely due to genetic differences, it should be possible to identify the responsible underlying allelic differences with the appropriate strategies given that the phenotypic differences are robust and amenable to experimental classification. Of interest, the FVB strain is derived from "Swiss albino" mice that do not have any common ancestors with many of the inbred mouse strains developed by the founders of the Jackson Laboratories [32] for which the $d b$ or $o b$ mutations have been studied. The exception is the SWR strain for which an SWR- $d b$ partial congenic line was analysed [4] although the phenotypes of the SWR- $d b$ and FVB- $d b$ strains are quite divergent. This is not unexpected since the Swiss albino mouse is actually a highly outbred stock.

We emphasise that the beta-cell expansion in obese F- $d b$ mice occurs in the presence of hyperglycaemia, a condition which has been shown to cause cytotoxic effects on rodent and human beta cells [33], and that the hyperglycaemia is produced by the extreme insulin resistance caused by the interaction of LEPR-deficiency and FVB-specific alleles. The beta-cell expansion of obese F- $d b$ mice produces enlarged, hypercellular islets that are dominated by beta cells. Whether this expansion is due to recruitment of precursor cells extrinsic to the islet or proliferation of intra-islet cells has yet to be assessed. The net production of beta cells could be due to a combination of (i) increased proliferation of beta cells and/or their precursors and (ii) de- 
creased rates of beta-cell death. In the case of beta-cell proliferation, it might be interesting to investigate expression of genes that have been implicated in controlling beta-cell mass, such as Igflr, Insr, Irs2, and the $M O D Y$ genes $[34,35,36]$. It would also be interesting to study the same set of genes in the regulation of cell death, in addition to the genes implicated in apoptosis, such as the $B A D$ family of genes [37]. Further studies to measure the rates of beta-cell turnover will be required to find the relative contributions of these two processes to the beta-cell mass expansion of obese FVB mice. The syndrome of hyperinsulinaemic hyperglycaemia is probably a trait intrinsic to the genetic makeup of the FVB strain since manipulations of adipose-tissue mass, either by the A-ZIP-F1 dominant negative transcription factor [31] or by the BAT-specific toxigene, UCP-diphtheria toxin transgene [30], in FVB mice cause a similar diabetes phenotype of hyperinsulinaemic hyperglycaemia as produced by disruption of the leptin-leptin receptor system in the F- $d b$ mice.

It is well documented that LEPR-deficiency, independent of strain, causes a defect in glucose-stimulated insulin secretion, both in the intact rodent [38] and in isolated islets [39]. Moreover, the increased insulin concentrations in the fed and fasting states of obese mice of both strains indicate that insulin resistance is the primary cause of glucose intolerance in LEP- and LEPR-deficient mice (Table 1 ). The new phenotype of interest shown by the FVB- $d b$ strain is the persistence of an expanded beta-cell mass in the context of prolonged hyperglycaemia. In particular, the dissociation of the loss of beta-cell mass from the development of hyperglycaemia in obese FVB mice suggests that there are genetic loci that can protect and enhance beta-cell mass, if not beta-cell function, within the context of prolonged hyperglycaemia. A search for the FVB loci that control beta-cell mass during hyperglycaemia could identify pathways involved in controlling betacell differentiation and/or proliferation in diabetes.

Obese B- $d b 3 J$ mice do not show any sexual dimorphism in glucose or insulin concentrations, although there is a dramatic sexual dimorphism in the glucose and insulin concentrations of obese mice of the F- $d b$ strain. However, a comparison of the QUICKI values indicates there are no differences due to sex in either the $\mathrm{F}-d b$ or the $\mathrm{B}-d b 3 J$ strains. This can be interpreted by postulating that there is a fixed insulin sensitivity determined by strain and Lepr genotype. This fixed insulin sensitivity then determines glucose concentrations according to ambient insulin concentrations. If hyperglycaemia is shown, insulin secretory capacity is increased by increasing pancreatic beta-cell mass as a compensatory mechanism to achieve euglycaemia. In the case of obese F- $d b$ mice, euglycaemia is not achieved in the fed state while euglycaemia in the fasted state is attained with insulin concentrations that are 20 to 30-fold over lean mice of both strains and two to threefold over obese B- $d b 3 J$ mice. Since LEPR-deficiency causes a hyperphagic state, it is reasonable to assume that the fed state and hyperglycaemia is the usual condition of obese F- $d b$ mice.

It might be that the DBA strain's variable diabetes phenotype makes it an undesirable strain for genetic studies. It is quite likely however, that the DBA strain contains a mixture of loci and alleles that have opposite effects on beta-cell proliferation and survival. Therefore, crosses with DBA could still prove useful if the presence of diabetes-protective, as well as diabetes-susceptible, alleles is studied in detail. The probable presence of both types of loci in any given mouse strain should be kept in mind. If the phenotypic variability of obese DBA- $o b$ mice is due to partial penetrance of a single locus, it would still be possible to identify the modifier locus by selecting those mice that show loss of beta cells, thus enriching for the alleles that predispose to diabetes. In such a case, the judicious selection of a counterstrain that shows very little phenotypic variability in terms of diabetes will be essential to the success of the project. It is also possible that the phenotypic variability is due to residual genetic heterogeneity in the DBA-ob congenic strain. We believe that this is unlikely since the mice are full congenics after ten backcross generations and a similar phenotypic variability was observed in an independently derived DBA-ob strain [4]. The possibility of multiple protective and susceptibility loci in the DBA strain could explain the extreme diabetessusceptibility of obese C57BLKS/J mice by supposing that the recombinant genome of BLKS mice (derived from both B6 and DBA strains) combined most of the diabetes-susceptibility loci of both strains as well as removing some of the diabetes-protective loci. It is estimated from genomic analysis of microsatellite markers that the BLKS genome is approximately $7 / 8$ C57BL/6J and 1/8 DBA [40].

The lack of a sex effect in obese DBA- $o b$ mice is somewhat surprising since other diabetes-susceptible strains show sexual dimorphism in diabetes susceptibility - CBA- $d b$ mice [41] and CD1- $d b-N C S U$ mice [32]. However, this sex-specific effect on diabetes susceptibility could have more to do with beta-cell responses than insulin sensitivity, as previously noted for very similar QUICKI indices between male and female obese F- $d b$ mice despite vastly different circulating insulin concentrations.

These strains provide the opportunity to carry out a genetic analysis of the factors involved in the compensatory response of pancreatic endocrine cells to hyperglycaemia [42]. The pancreatic beta-cell compartment undergoes dynamic turnover with a certain fraction of cells being replaced over time [43]. The beta cells can respond to an increased demand for insulin by hyperplasia and hypertrophy and can also respond to diminished requirements by reducing beta-cell mass. Our observations of the obese FVB mice indicate that 
hyperplasia and increased beta-cell mass can be maintained in the presence of severe hyperglycaemia.

Obese FVB mice, both F- $d b$ and F- $o b$, survive for more than 12 months with only moderate attention to their fluid requirements. The increased mesangial matrix indicates that the long-term hyperglycaemichyperinsulinaemic state could produce histopathological changes in obese FVB mice, although no functional changes were observed. These observations are in line with observations in other LEPR-deficient models where mesangial matrix expansion is seen with little or no functional changes. We did not observe any glomerular changes in obese $\mathrm{B}-d b 3 \mathrm{~J}$ mice. This is not surprising due to the lack of overt hyperglycaemia in these mice and the classification of the C57BL/6J strain as being resistant to developing glomerulosclerosis $[44,45]$ using a completely different genetic model. Our results are interesting because LEPR-deficient C57BLKS/J- $d b$ mice, the parent strain of the F- $d b$ and the B- $d b$ strains, are hyperglycaemic and show signs of diabetic nephropathy with alterations in functional measures such as creatinine clearance [46]. Thus, it is highly likely that these mice will be useful for longterm studies regarding the effects of hyperglycaemia and hyperinsulinaemia in various tissues.

Acknowledgements. This work was supported by the following grants: New York Obesity Research Center (DK26687) and International Consortium for the Identification of Genes for Type 2 Diabetes and Obesity (Eli Lilly Company).

\section{References}

1. Coleman DL (1978) Obese and diabetes: two mutant genes causing diabetes-obesity syndromes in mice. Diabetologia 14:141-148

2. Leiter EH, Coleman DL, Eisenstein AB, Strack I (1980) A new mutation $(\mathrm{db} 3 \mathrm{~J})$ at the diabetes locus in strain $129 / \mathrm{J}$ mice. I. Physiological and histological characterization. Diabetologia 19:58-65

3. Hummel KP, Dickie MM, Coleman DL (1966) Diabetes, a new mutation in the mouse. Science 153:1127-1128

4. Leiter EH, Coleman DL, Hummel KP (1981) The influence of genetic background on the expression of mutations at the diabetes locus in the mouse. III. Effect of H-2 haplotype and sex. Diabetes 30:1029-1034

5. Ikeda H, Shino A, Matsuo T, Iwatsuka H, Suzuoki Z (1981) A new genetically obese-hyperglycemic rat (Wistar fatty). Diabetes 30:1045-1050

6. Friedman JE, Vente JE de, Peterson RG, Dohm GL (1991) Altered expression of muscle glucose transporter GLUT-4 in diabetic fatty Zucker rats (ZDF/Drt-fa). Am J Physiol 261:E782-E788

7. Orci L, Ravazzola M, Baetens D et al. (1990) Evidence that down-regulation of beta-cell glucose transporters in noninsulin-dependent diabetes may be the cause of diabetic hyperglycemia. Proc Natl Acad Sci USA 87:9953-9957

8. Michaelis OE, Ellwood KC, Judge JM, Schoene NW, Hansen CT (1984) Effect of dietary sucrose on the SHR/Ncorpulent rat: a new model for insulin-independent diabetes. Am J Clin Nutr 39:612-618
9. Ellwood KC, Michaelis OE, Emberland JJ, Bhathena SJ (1985) Hormonal and lipogenic and gluconeogenic enzymatic responses in LA/N-corpulent rats. Proc Soc Exp Biol Med 179:163-167

10. Leiter EH, Prochazka M, Shultz LD (1987) Effect of immunodeficiency on diabetogenesis in genetically diabetic (db/db) mice. J Immunol 138:3224-3229

11. Leiter EH, Coleman DL, Eisenstein AB, Strack I (1981) Dietary control of pathogenesis in $\mathrm{C} 57 \mathrm{BL} / \mathrm{KsJ} \mathrm{db} / \mathrm{db}$ diabetes mice. Metabolism 30:554-562

12. Schreyer SA, Chua SC Jr, LeBoeuf RC (1998) Obesity and diabetes in TNF-alpha receptor-deficient mice. J Clin Invest 102:402-411

13. Chung WK, Chua SC, Lee GH, Leibel RL (1997) Polymerase chain reaction-restriction fragment length polymorphisms (PCR-RFLP) and electrophoretic assays for the mouse obese (Lepob) mutation. Obes Res 5:183-185

14. Kowalski TJ, Liu SM, Leibel RL, Chua SC Jr (2001) Transgenic complementation of leptin-receptor deficiency. I. Rescue of the obesity/diabetes phenotype of LEPR-null mice expressing a LEPR-B transgene. Diabetes 50:425-435

15. Kodama H, Fujita M, Yamaguchi I (1994) Development of hyperglycaemia and insulin resistance in conscious genetically diabetic (C57BL/KsJ-db/db) mice. Diabetologia 37:739-744

16. Katz A, Nambi SS, Mather K et al. (2000) Quantitative insulin sensitivity check index: a simple, accurate method for assessing insulin sensitivity in humans. J Clin Endocrinol Metab 85:2402-2410

17. Reeves PG, Nielsen FH, Fahey GC Jr (1993) AIN-93 purified diets for laboratory rodents: final report of the American Institute of Nutrition ad hoc writing committee on the reformulation of the AIN-76A rodent diet. J Nutr 123:1939-1951

18. Taketo M, Schroeder AC, Mobraaten LE et al. (1991) FVB/N: an inbred mouse strain preferable for transgenic analyses. Proc Natl Acad Sci USA 88:2065-2069

19. Tober C, Krause U, Beyer J, Herberg L (1979) Studies with crystalline insulin from obese and lean mice of the BL/6J strain. Horm Metab Res 11:195-200

20. Chua SC Jr (1997) Monogenic models of obesity. Behav Genet 27:277-284

21. Campfield LA, Smith FJ, Guisez Y, Devos R, Burn P (1996) OB protein: a peripheral signal linking adiposity and central neural networks. Appetite 26:302

22. Anand A, Chada K (2000) In vivo modulation of Hmgic reduces obesity. Nat Genet 24:377-380

23. Erickson JC, Hollopeter G, Palmiter RD (1996) Attenuation of the obesity syndrome of ob/ob mice by the loss of neuropeptide Y. Science 274:1704-1707

24. Coleman DL (1982) Thermogenesis in diabetes-obesity syndromes in mutant mice. Diabetologia 22:205-211

25. Ewart-Toland A, Mounzih K, Qiu J, Chehab FF (1999) Effect of the genetic background on the reproduction of leptin-deficient obese mice. Endocrinology 140:732-738

26. Coleman DL, Leiter EH, Applezweig N (1984) Therapeutic effects of dehydroepiandrosterone metabolites in diabetes mutant mice (C57BL/KsJ-db/db). Endocrinology 115:239-243

27. Gibbs EM, Stock JL, McCoid SC et al. (1995) Glycemic improvement in diabetic $\mathrm{db} / \mathrm{db}$ mice by overexpression of the human insulin-regulatable glucose transporter (GLUT4). J Clin Invest 95:1512-1518

28. Arvaniti K, Huang Q, Richard D (2001) Effects of leptin and corticosterone on the expression of corticotropinreleasing hormone, agouti-related protein, and proopiomelanocortin in the brain of ob/ob mouse. Neuroendocrinology 73:227-236 
29. Zhang B, Graziano MP, Doebber TW et al. (1996) Downregulation of the expression of the obese gene by an antidiabetic thiazolidinedione in Zucker diabetic fatty rats and $\mathrm{db} / \mathrm{db}$ mice. J Biol Chem 271:9455-9459

30. Lowell BB, Hamann SS, Lawitts JA et al. (1993) Development of obesity in transgenic mice after genetic ablation of brown adipose tissue. Nature 366:740-742

31. Moitra J, Mason MM, Olive M et al. (1998) Life without white fat: a transgenic mouse. Genes Dev 12:31683181

32. Brown JA, Chua SC Jr, Liu SM, Andrews MT, Vandenbergh JG (2000) Spontaneous mutation in the db gene results in obesity and diabetes in CD-1 outbred mice. Am J Physiol Regul Integr Comp Physiol 278:R320-R330

33. Leahy JL, Bonner-Weir S, Weir GC (1992) Beta-cell dysfunction induced by chronic hyperglycemia. Current ideas on mechanism of impaired glucose-induced insulin secretion. Diabetes Care 15:442-455

34. Bell GI, Polonsky KS (2001) Diabetes mellitus and genetically programmed defects in beta-cell function. Nature 414:788-791

35. Kahn CR, Bruning JC, Michael MD, Kulkarni RN (2000) Knockout mice challenge our concepts of glucose homeostasis and the pathogenesis of diabetes mellitus. J Pediatr Endocrinol Metab 13 [Suppl 6]:1377-1384

36. Withers DJ, Burks DJ, Towery HH, Altamuro SL, Flint CL, White MF (1999) Irs-2 coordinates Igf-1 receptor-mediated beta-cell development and peripheral insulin signalling. Nat Genet 23:32-40

37. Federici M, Hribal M, Perego L et al. (2001) High glucose causes apoptosis in cultured human pancreatic islets of Langerhans: a potential role for regulation of specific $\mathrm{Bcl}$ family genes toward an apoptotic cell death program. Diabetes 50:1290-1301
38. Harmon JS, Gleason CE, Tanaka Y, Poitout V, Robertson RP (2001) Antecedent hyperglycemia, not hyperlipidemia, is associated with increased islet triacylglycerol content and decreased insulin gene mRNA level in Zucker diabetic fatty rats. Diabetes 50:2481-2486

39. Wang MY, Koyama K, Shimabukuro M, Newgard CB, Unger RH (1998) OB-Rb gene transfer to leptin-resistant islets reverses diabetogenic phenotype. Proc Natl Acad Sci USA 95:714-718

40. Naggert JK, Mu JL, Frankel W, Bailey DW, Paigen B (1995) Genomic analysis of the C57BL/Ks mouse strain. Mamm Genome 6:131-133

41. Leiter EH (1981) The influence of genetic background on the expression of mutations at the diabetes locus in the mouse IV. Male lethal syndrome in CBA/Lt mice. Diabetes 30:1035-1044

42. Weir GC, Laybutt DR, Kaneto H, Bonner-Weir S, Sharma A (2001) Beta-cell adaptation and decompensation during the progression of diabetes. Diabetes 50 [Suppl 1]:S154-S159

43. Bonner-Weir S (2001) beta-cell turnover: its assessment and implications. Diabetes 50 [Suppl 1]:S20-S24

44. Lenz O, Zheng F, Vilar J et al. (1998) The inheritance of glomerulosclerosis in mice is controlled by multiple quantitative trait loci. Nephrol Dial Transplant 13:3074-3078

45. Esposito C, He CJ, Striker GE, Zalups RK, Striker LJ (1999) Nature and severity of the glomerular response to nephron reduction is strain-dependent in mice. Am J Pathol 154:891-897

46. Ziyadeh FN, Hoffman BB, Han DC et al. (2000) Longterm prevention of renal insufficiency, excess matrix gene expression, and glomerular mesangial matrix expansion by treatment with monoclonal antitransforming growth factorbeta antibody in db/db diabetic mice. Proc Natl Acad Sci USA 97:8015-8020 